\title{
Rainwater harvesting in Brazil: investigating the viability of rainwater harvesting for a household in Brasília
}

\author{
D. Sant'Ana \\ Oxford Institute for Sustainable Development, \\ Department of Architecture, Oxford Brookes University, Oxford, UK
}

\begin{abstract}
This paper addresses the issue of harvesting rain for later use, as part of a decentralised sustainable urban water management scheme, by adapting an existing house in order to study the viability of rainwater harvesting (RWH) systems. The goal of this study was to investigate the potential solutions for the application of a domestic RWH system for a household in Brasília and identify the most favourable system for such, considering water conservation and its economic viability. Based on the investigated the household's total annual water consumption and rainwater yield capacity, two RWH systems were proposed: a treated and a potable indirectly pumped system. The treated RWH system, used for toilet flushing, dish washing, clothes washing and sink washing, is capable of conserving $222.65 \mathrm{~m}^{3} / \mathrm{yr}$ of potable water. Considering the total annual savings of $\mathrm{R} \$ 1,962.54$ (US\$882.71), this system has a payback period of approximately 11 years. The potable RWH system, applied to the existing plumbing, supplies potable rainwater into a pre-existing water tank for all uses. This system presented a lower payback period of $91 / 2$ years, is able to conserve $456.25 \mathrm{~m}^{3} / \mathrm{yr}$ of mains water and contains a total annual savings of R $\$ 3,659.29$ (US $\$ 1,645.88$ ). The potable RWH system conserves more water, and has a lower payback period than the treated RWH system because it harvests and uses more rainwater. Although, there is a setback, the potable system contains a much higher capital cost and operational cost, requiring a higher initial investment capital and annual expenses.

Keywords: rainwater use and harvesting systems, rainwater tank performance, potable water savings, cost-benefit analysis, viability of rainwater harvesting in Brazil.
\end{abstract}




\section{Introduction}

Water is the most precious of all resources, to sustain it, is to preserve life. According to the Agencia Nacional das Águas - ANA (National Water Agency), it is estimated that the capacity to supply fresh water to the city of Brasilia will be exhausted by 2007 [1]. In order to meet the demand, the construction of a fifth water catchment system, the Corumbá $I V$ water dam, is taking place. The implementation, operation and maintenance of large scale systems are becoming complex and costly. Because of this, most environmental specialists believe that future urban water management will have to be decentralised, with small scale systems such as rainwater harvesting, in order to preserve and maintain precious ecosystems threatened by the large scale urban water and waste management schemes. The exploitation of further hydrologic resources, as well as being environmentally unfriendly, could only solve the supply issues for the city on a mid-term level. The actual problem lies within the exceeding water consumption of the city, where for example, the enormous water consumption rate of 829L/person/day at the Lago Sul neighbourhood of Brasília [2] is four times larger than the generous average quota of $200 \mathrm{~L} /$ person/day estimated by Gould and Petersen [3].

Collecting rainwater from buildings is a simple concept promoting selfsufficiency, water conservation and minimises local erosion or flooding caused by run-off. A mass scale use of rainwater harvesting on buildings may possibly aid on minimising the impact of floods on cities as well as reducing the demand of freshwater by storing storm water to be consumed later on. Precipitation has the advantage of being relatively pure, oxygenated and free. Treated rainwater can be safely used for toilet flushing, washing and irrigation [4]. Therefore the use of rainwater on buildings could play an important role on water conservation and sustainability.

\section{Objective}

The idea of retaining rainwater for reuse as part of a decentralised sustainable urban water management scheme for the city of Brasília, addresses the issue of adapting existing buildings in order to apply such systems. This study shall investigate the possibility of adapting a typical house at Lago Norte, as well as identifying the optimal rainwater system for it. Formulating the possibilities of rainwater system for domestic supply depends largely upon its water consumption patterns and the volume of gathered rainfall. As the price for water rises, due to the limited offer and the growing demand, a cost-benefit analysis linked with the amount of water harvested and therefore conserved, should also be analysed in conjunction with the system's cost. The overall aim of this investigation is to analyse the possible solutions towards the application of a rainwater harvesting system for a house in Brasília, Brazil and pinpoint its optimum harvesting system considering water conservation and feasibility. 


\section{Methodology}

Initially, with the intention of determining the optimal rainwater harvesting system for the investigated house, an overview of existing system types and possible configurations linked with an estimated annual rainwater yield capacity is necessary. By assembling the site's rainfall data and assessing the existing catchment area, an estimated monthly rainwater supply can be determined. With this, a cross reference of rainwater supply patterns and possible domestic water demand can be done to propose a potential rainwater harvesting system. The estimated water savings can be obtained through modelling the recommended rainwater system, followed by an annual simulation of monthly harvesting and consumption patterns of rainwater. This simulation shall also assist on sizing the storage tank of the system, considering its security of supply. In order to assess the proposed rainwater harvesting system's feasibility, the comparison of the estimated total capital cost of equipment and installation together with the cost of mains water saved, provides the predicted payback period of the system at hand.

\section{Case study}

The investigated five bedroom house, with a total area of $483 \mathrm{~m}^{2}$, is located on an $8,000 \mathrm{~m}^{2}$ plot of land near the banks of Brasília's artificial lake, Lago Paranoá, situated in the neighbourhood of Lago Norte. Within the site, a swimming pool is topped up with mains water on the average of once a year. The house is mains connected, receiving potable water from the local water facilities company $C A E S B$, which supplies potable water for a total of six people. This water is fed to a 2,000 litres mains water tank located within the loft of this residential construction, which is later delivered to points of use in the house by gravity. External consumption of water, such as garden irrigation, car and floor washing, is supplied by an underground water well located within the site. The underground water is extracted via water pump and is fed to external taps located throughout the garden.

\subsection{Domestic water demand}

The metered data collected from the investigated house for the period of one year indicates that the average daily water consumption is $1.25 \mathrm{~m}^{3}$ from the total annual consumption of $455 \mathrm{~m}^{3}$, fig. 1. Having six household members living in the house, the daily water consumption per capita for the period of August 2004 to July 2005 is of $207.8 \mathrm{~L} /$ person/day.

\subsection{Estimating rainwater supply}

The average volume (L) of the annual rainwater yield $Y_{t}$ can be calculated by the product of the amount of rainfall $(\mathrm{mm})$ available over a period of time $R_{t}$, its possible collection from a catchment area $A\left(\mathrm{~m}^{2}\right)$ in relation to its runoff coefficient $C_{r}$ and the system's filter efficiency coefficient $C_{f}[4]$. 


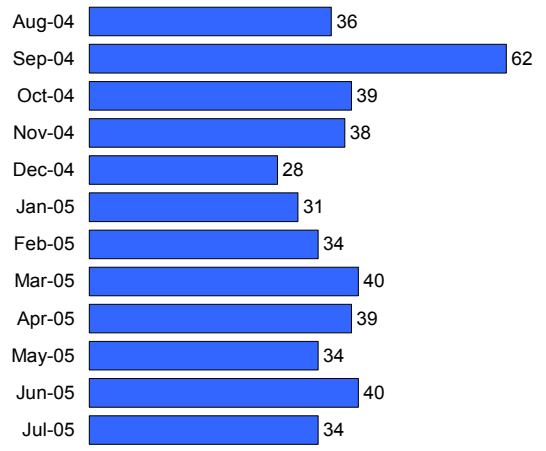

Figure 1: $\quad$ Metered mains water readings of the site $\left(\mathrm{m}^{3}\right.$ per month).

$$
Y_{t}=R_{t} \times A \times C_{r} \times C_{f}
$$

\subsubsection{Rainfall data}

Brasilia's average annual precipitation is $1,502 \mathrm{~mm}$, and its rainfall patterns consists of dense tropical rains during the summer, specially in the months between November to February with precipitation reaching up to the average $250 \mathrm{~mm}$, and dry winters, having only an average $5 \mathrm{~mm}$ of rain in the month of June, fig. 2.

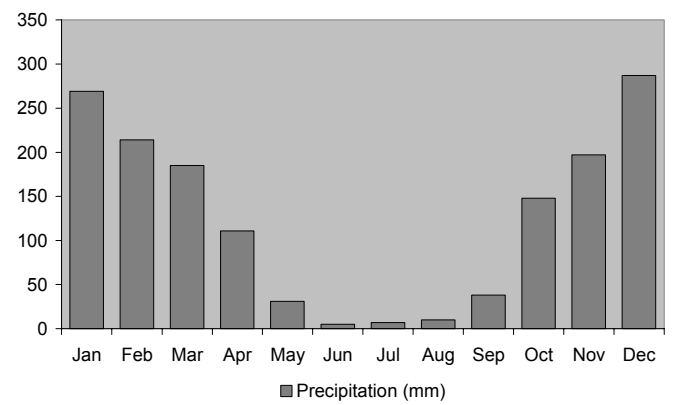

Figure 2: Brasília’s average annual precipitation. Source: METEONORM V. 4.0.

\subsubsection{Catchment surface area}

The investigated household at hand contains a sloped roof, having a plan area of $468.63 \mathrm{~m}^{2}$, and is covered with terracotta tiles. The roof does not contain any gutters and down pipes, therefore the installation of such would be required for a RWH system, which would add up to its final cost.

\subsubsection{Runoff coefficient}

Runoff coefficients of varied catchment surfaces have been developed by researchers and system manufacturers in order to identify the possible rainwater 
losses of every roof and ground catchment type. Having a sloped terracotta tile rooftop, a runoff coefficient of 0.8 was adopted for the investigated household.

\subsubsection{Filter efficiency coefficient}

With a plan roof area of $468.63 \mathrm{~m}^{2}$, the optimal filter for the given situation would be to use a subsurface filter, which is able to deliver filtered rainwater with $90 \%$ efficiency for catchment areas up to $500 \mathrm{~m}^{2}$.

\subsubsection{Annual rainwater yield}

In theory, the estimated volume of $506.80 \mathrm{~m}^{3}$ of rainwater harvested, would be able to completely supply the annual household demand of $455 \mathrm{~m}^{3}$. Further investigation of monthly rainwater supply and domestic water demand would be necessary due to the unstable rainfall patterns, where dry months could pose a supply issue.

\subsection{Identifying possible rainwater use}

\subsubsection{Untreated Rainwater Use}

Untreated rainwater can be used for garden irrigation and external washing. However, in this case, the household already makes use of free underground water for such purposes and therefore investing on a RWH system would bring no pay back.

\subsubsection{Treated rainwater use}

Treated rainwater could be used in the house for toilet flushing, dish washing, clothes washing and sink washing providing some refurbishment to the building is done. By adopting previous studies on water consumption patterns for Brazil [5], where the WC flushing, dish washer, washing machine and washing sink represents a total of $49 \%$ of the entire domestic water use, it is possible to estimate the overall volume of rainwater required for such supply. Having a mean annual water consumption of $455 \mathrm{~m}^{3}$, for such system, the household would require an average of $222.95 \mathrm{~m}^{3}$ of rainwater supply.

The overlapping total estimated potential rainwater yield of $507.80 \mathrm{~m}^{3}$ implies that, for the system at hand, a partial runoff catchment from the roof area could provide the necessary volume. By using the $228.85 \mathrm{~m}^{2}$ portion of available roof area, the total average annual rainwater yield of $247.50 \mathrm{~m}^{3}$, would offer the required water volume.

\subsubsection{Potable rainwater use}

Due to a series of possible contaminants and pathogens encountered within rainwater, suitable disinfection is necessary after a microfiltration process, if such water is to be used for potable purposes and other domestic uses such as bathing and washing. In this case, an indirectly pumped system could be easily applied to the pre-existing plumbing with minor refurbishment, by supplying potable rainwater into the existing water tank. Although this would represent a lower cost in refurbishment, safety issues such as electronic fail-safe controls and equipment which are extremely crucial to provide the necessary health safety 
guard, can raise the cost of the system. Another factor to take into consideration for analysing this system's cost-benefit would be periodical maintenance such as UV lamps replacement and system check-up.

\subsection{Proposed rainwater harvesting systems}

\subsubsection{Treated RWH system}

The schematic flow diagram of such RWH system represents the design and treatment process of this proposed system, fig. 3. As rainfall is collected by the gutters, an initial screen filtration removes coarse debris as a prevention of downpipe clogging. A subsurface filter provides a finer filtration with a $0.44 \mathrm{~mm}$ grid and is connected to the stormwater drain pipe, where debris is washed away through a self-cleaning action. The calmed inlet delivers the filtered rainwater to an underground collection tank without disturbing the sedimentation layer of settled impurities, as well as providing slight aeration to the stored water. An overflow unit removes suspended impurities of the water during rainy season, having a backflow protection valve and a grill to prevent unwanted contaminants and animals within the tank. During dry periods, mains water is toped-up to the collection tank when necessary. A float switch located inside the collection tank triggers a magnetic valve, feeding mains water into the tank through the calmed inlet. The floating suction filter provides fine filtration with its $0.23 \mathrm{~mm}$ filter mesh and extracts rainwater where it is cleanest, therefore reducing the wear of the pump, which is activated by a float switch when required, located within a distribution tank. This water can then be fed to points of use through gravity.

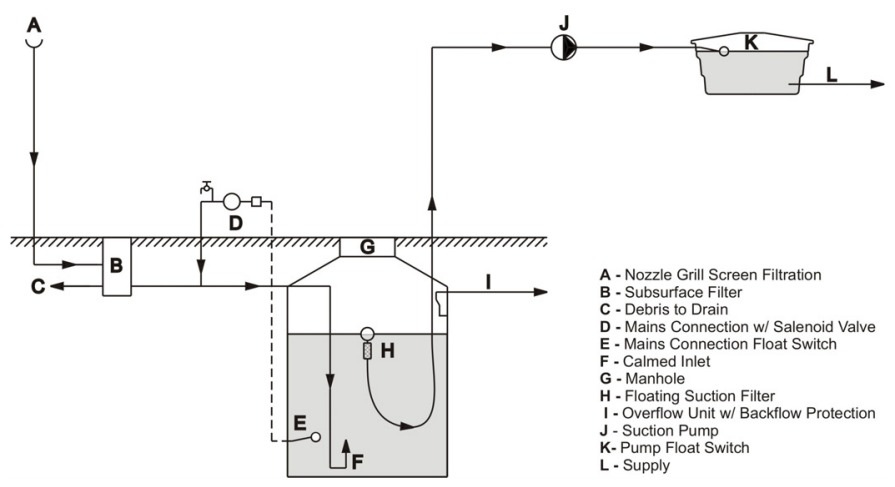

Figure 3: $\quad$ Flow diagram of proposed treated RWH system.

\subsubsection{Potable RWH system}

The schematic flow diagram of such potable RWH system represents the design and treatment process of this proposed system, fig. 4. This system contains the same filtration process as the previously proposed treated RWH system, but before the filtered rainwater is fed to the distribution tank, disinfection is crucial. Therefore, a 25 and a 5 micron microfiltration is necessary before UV sterilization can take place. In order to guarantee a fail safe system, the 
ultraviolet treatment unit is equipped with an automatic shut-off control. In case rainwater does not receive the appropriate level of UV radiation, this device automatically prevents the untreated rainwater from entering the distribution tank by restricting its flow. The disinfected, therefore potable water, delivered to the distribution tank, can be fed to points of use through gravity.

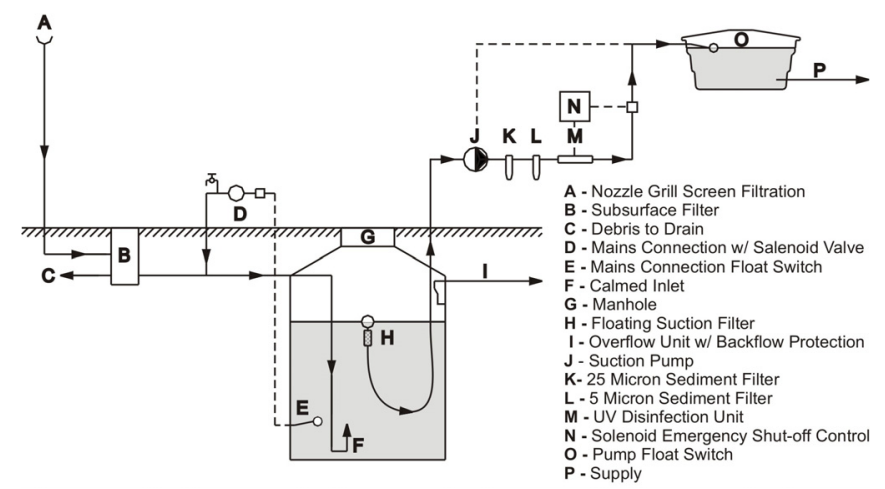

Figure 4: $\quad$ Flow diagram of proposed potable RWH system.

\subsection{Sizing the rainwater tank}

Gould and Petersen [3], indicate a practical and effective graphical method of mass curve analysis to identify the most appropriate tank volume. This method makes use graphics to illustrate the volume of harvested rain and water consumption, over a time interval. By plotting the cumulative average rainwater supply, and cross referencing this information with the average cumulative water demand, it is possible to identify the volume of storage needed. This graphical representation also aids on pointing out periods the tank would need top-up from mains water in order to provide the necessary volume of water.

\subsubsection{Treated RWH system tank}

In order to determine the necessary tank volume for the proposed treated RWH system, a cumulative mean rainwater yield is cross referenced with the average rainwater consumption for the period of one year, fig. 5a. So as to simplify the model, the assumption a constant daily consumption of $0.61 \mathrm{~m}^{3}$ is used, given the estimated total $222.95 \mathrm{~m}^{3}$ of rainwater consumption for toilet flushing, dish washer, washing machine and washing sink. For one year, the graph demonstrates that from August to November, mains top-up would be required to supply the necessary water for consumption.

When this graph is to be plotted for a period of five years, it indicates a progressive rainfall yield compared to the constant rainwater consumption. As a result, mains water top-up would not be required after the simulated second year because by the end of each year approximately $25 \mathrm{~m}^{3}$ of rainwater would add up to the following year. Considering that a commercially available $30 \mathrm{~m}^{3}$ rainwater tank is applied to the system, its performance is simulated by determining how 
much rainwater it contains through a period of five years, assuming the above supply and consumption factors. Such performance indicates rainwater overflows at its maximum level of $30 \mathrm{~m}^{3}$, and after the third year, the tank reaches its maximum efficiency, fig. $5 b$.

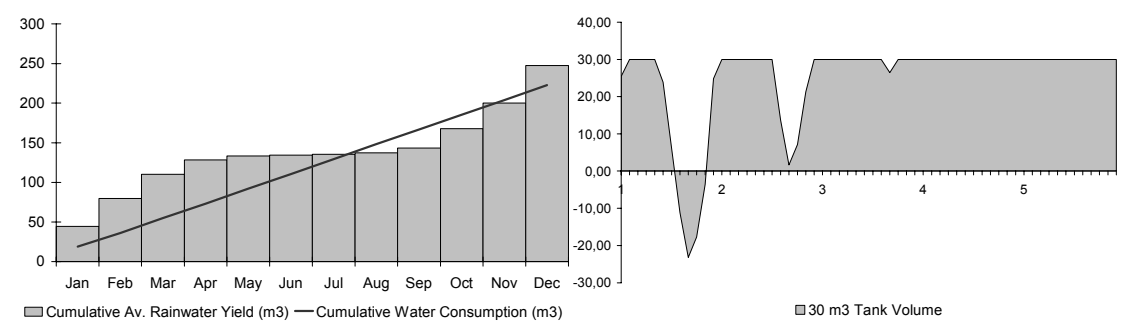

(a)

(b)

Figure 5: Monthly cumulative supply and demand (a) and rainwater tank performance (b).

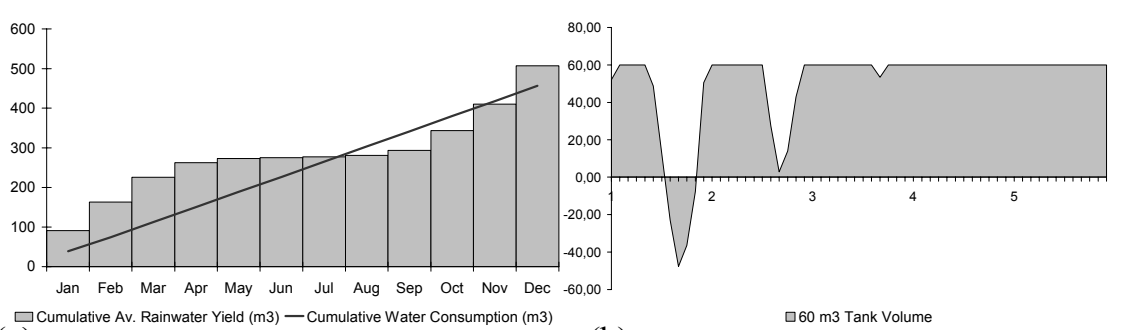

(a)

Figure 6: Monthly cumulative supply and demand (a) and rainwater tank performance (b).

\subsubsection{Potable RWH system tank}

Using the same technique as above, a cumulative mean rainwater yield is cross referenced with the average rainwater consumption for the period of one year in order to determine the required reservoir volume for the proposed potable RWH system, fig. 6a. Assuming the total average daily consumption of $1.25 \mathrm{~m}^{3}$, the graph demonstrates that during the months of August to November, the collection tank would be empty and such system would require mains top-up during this period.

The five-year simulation of its cumulative supply and demand reveals an arithmetic progression of around $50 \mathrm{~m}^{3}$ rainfall yield per year due to annual surplus, compared to its constant rainwater consumption. Due to such progression, mains water top-up is only necessary for the first two years. Considering two commercially available rainwater tanks of $30 \mathrm{~m}^{3}$ are applied to the system, the tanks' performance can be simulated by determining the rainwater volume contained within through a period of five years, assuming the 
above supply and consumption factors, fig. 6b. Such performance indicates rainwater overflows at its maximum level of $60 \mathrm{~m}^{3}$, and after the third year, the tank reaches its maximum efficiency.

\section{Cost-benefit analysis}

The cost-benefit analysis of the RWH systems includes an analysis upon the total cost of a system, in relation to present and future mains water cost. In order to identify the payback period of a system, its total cost should be divided by the annual savings the system in hand generates.

$$
\text { Payback Period }(y r)=\frac{\text { Total System Cost }}{\text { Total Annual Savings }}
$$

Predicted annual savings of RWH system can be identified by the product of the volume of monthly water saved and the price of mains water within one year, where:

$$
\text { Savings }(R \$ / y r)=\sum_{1}^{12}\left(\text { Monthly Volume Saved }\left(m^{3}\right) \text { x Mains Water Cost }\left(R \$ / m^{3}\right)\right)
$$

Operational costs should also be considered in order to obtain a more precise prediction of annual savings. Many RWH systems consume energy, require specialised labour and demand parts replacement. These annual expenses contribute to the deduction of a system's annual savings, where:

$$
\text { Total Annual Savings }(R \$)=\text { Annual savings }- \text { Operational cost }
$$

\subsection{Treated RWH system analysis}

The proposed treated rainwater system has a total cost of $\mathrm{R} \$ 21,044.56$ (US\$9,465.46), with an annual operating cost of R\$188.26 (US\$84.67) and generates an annual savings of R $\$ 2,150.80$ (US\$967.39). Having a total annual savings of $\mathrm{R} \$ 1,962.54$ (US\$882.71), this system's payback period is of almost 11 years.

\subsection{Potable RWH system analysis}

The proposed potable rainwater system generates a savings of $\mathrm{R} \$ 4,407.18$ (US\$1,982.26) per year, has an annual operating cost of R $\$ 748.09$ (US\$336.48) and needs an initial investment of R $\$ 34,336.95$ (US\$15,444.10). With the total annual savings of $R \$ 3,659.29$ (US\$1,645.88), this system has a payback period of approximately $9 \frac{1}{2}$ years.

\section{Conclusion}

This study proposes two types of indirectly pumped systems: a treated RWH system and a potable RWH system. Since the site already makes use of 
underground water for irrigation and other external uses like car and floor washing, such untreated uses were ruled out. The proposed treated RWH system costs $\mathrm{R} \$ 21,044.56$ (US\$9,465.46), conserves $222.65 \mathrm{~m}^{3}$ of water and saves $\mathrm{R} \$ 2,150.80$ (US\$967.39) per annum. Considering the system's annual operating cost of $\mathrm{R} \$ 188.26$ (US\$84.67), that reduces its annual savings to $\mathrm{R} \$ 1,962.54$ (US\$882.71), leads to a payback period of approximately 11 years. The proposed potable RWH system presented a lower payback period of just about $9 \frac{1}{2}$ years, being able to conserve $456.25 \mathrm{~m}^{3}$ per year. The potable system would require a higher investment of $\mathrm{R} \$ 34,336.95$ (US $\$ 15,444.10)$ to install it, having an annual operational cost of R $\$ 748.09$ (US\$336.48). The potable RWH system conserves more water, and has a lower payback period than the treated RWH system because it harvests and uses more rainwater. Although, there is a setback, the potable system contains a much higher capital cost and operational cost, requiring a higher initial investment capital and annual expenses. Actually, both systems present a medium term payback period and perhaps it would be necessary some sort of public financing with low interest rate and long-term credit in order to convince households to invest on them. Or, what is the same, introduce a discount in the water and sewage bill for the households who have installed it.

\section{References}

[1] Fonseca, A., A ordem e economizar água, Correio Braziliense, 16 February 2005.

[2] CAESB, http://www.caesb.df.gov.br/.

[3] Gould, J. and Petersen, E., Rainwater Catchment Systems for Domestic Supply: Design, construction and implementation. London: ITDG Publishing 1999.

[4] Leggett, D., Brown, R., Brewer, D., Stanfield G. and Holliday, E., Rainwater and greywater use in buildings: Best practice guidance. London: CIRIA, 2001.

[5] Santos, G. and Poledna, S., Meio Ambiente, Reciclagem e Tratamento de Resíduos. Sistema Brasileiro de Resposta Técnica. Ministério da Ciência e Tecnologia: SENAI, 2005. 